\title{
Arsenic occurrence in water bodies in Kharaa river basin
}

\author{
T.Azzaya*, G.Burmaa, S.Alen, T.Narangarav, Sh.Nyamdelger \\ Institute of Chemistry and Chemical Technology, Mongolian Academy of Sciences, MAS $4^{\text {th }}$ building, \\ Peace Avenue, Bayanzurkh district, Ulaanbaatar 13330, Mongolia \\ *Corresponding author: azzaya.usb@gmail.com
}

Received:10 October 2017; revised:13 December; accepted: 15 December 2017

\begin{abstract}
Distribution of arsenic (As) and its compound and related toxicology are serious concerns nowadays. Gold mining activity is one of the anthropogenic sources of environmental contamination regarding As and other heavy metals. In Mongolia, the most productive gold mining sites are placed in the Kharaa river basin. A hundred water samples were collected from river, spring and deep wells in this river basin. Along with total As and its species-As(III) and $A s(V)$, examination of concentration levels of other key parameters, 21 heavy metals with $\mathrm{pH}$, total hardness, electric conductivity, anion and cations, was also carried out. In respect to the permissible limit formulated by the Mongolian National Drinking water quality standard (MNS 0900:2005, As $10 \mu \mathrm{g} / \mathrm{l})$, the present study showed that most of samples were found no contamination. In Kharaa river basin, an average concentration of total As in surface water was $4.04 \mu \mathrm{g} / \mathrm{l}$ with wide range in $0.07-30.30 \mu \mathrm{g} / \mathrm{l}$ whereas it was $2.24 \mu \mathrm{g} / \mathrm{l}$ in groundwater. As analysis in surface water in licensed area of Gatsuurt gold mining showed a mean concentration with $24.90 \mu \mathrm{g} / \mathrm{l}$ presenting higher value than that of value in river basin by 6 orders of magnitude and it was 2 times higher than permissible level as well. In Boroo river nearby Boroo gold mining area, As concentration in water was ranged in 6.05-6.25 $\mu \mathrm{g} / \mathrm{l}$. Ammonia pollution may have present at estuary of Zuunmod river in Mandal sum with above the permissible level described in national water quality standard. Geological formation of the rocks and minerals affected to change of heavy metal concentration, especially As and uranium $(U)$ at spring water nearby Gatsuurt-Boroo improved road.
\end{abstract}

Key words: Arsenic, water quality, surface and groundwater, Kharaa river basin

\section{INTRODUCTION}

Arsenic (As) is a toxic metalloid and the 20th most abundant element in the earth's crust. It is predominantly present in inorg anic form $\left(\mathrm{As}^{3+}\right.$ and $\mathrm{As}^{5+}$ ) in aquatic system with a minor amount of methyl and dimethyl arsenic compounds. Arsenic in the water is a serious natural calamity and a public health hazard, which originates from natural systems including anthropogenic as well as geological sources [1]. In a bulletin of WHO report, Smith et al. [2] indicated studies in other countries where the population has had long-term exposure to arsenic in groundwater and further posited that 1 in 10 people who drink water containing $500 \mu \mathrm{g} / \mathrm{l}(0.5 \mathrm{mg} / \mathrm{l})$ of arsenic may ultimately die from cancers and non-cancers (e.g. cardiovascular diseases, diabetes, anemia, reproductive, developmental, immunological, and neurological effects) caused by arsenic, including lung, bladder and skin cancers. In recognition of the potential health risks, WHO has reduced its recommended maximum value for As in drinking water from $50 \mu \mathrm{g} / \mathrm{l}$ to a provisional value of $10 \mu \mathrm{g} / \mathrm{l}$. In areas where chronic endemic arsenosis problems are occurring, concentrations of As in drinking water are significantly higher than this recommended limit, sometimes in excess of $1 \mathrm{mg} / \mathrm{l}[3]$.
Arsenic found in the environment generally results from a combination of natural processes (weathering, biological activity and volcanic emissions) and anthropogenically induced activities including mining, fuel combustions, wood preservation, the use of As-based pesticides in agriculture, etc. These actions are responsible for the emission of As into the atmosphere, from where it redistributes on the earth's surface by means of dry fallout and rain.

Gold mining activities are important sources of arsenic and other heavy metals in the environment, which may result in considerable water or soil contamination. Recently, heavy metal such as arsenic, cadmium, contamination of surface and groundwater, agricultural soils and crops in mining areas have been identified as one of the most serious environmental problems in several countries of the world including Korea, Mexico, India, China, France and Spain [4-7]. In Mongolia, the most productive gold mining sites including Boroo and Gatsuurt are located in the Kharaa river basin, which is one of the main tributaries of Orkhon-Selenge river basin. The river basin has special importance in the sector of mining, agriculture, animal husbandry and tourism. While a comprehensive quality monitoring for ground

(C) The Author(s). 2017 Open access This article is distributed under the terms of the Creative Commons Attribution 4.0 International License (http://creativecommons.org/licenses/by/4.0/), which permits unrestricted use, distribution, and reproduction in any medium, provided you give appropriate credit to the original author(s) and the source, provide a link to the Creative Commons license, and indicate if changes were made. 
and surface as well as drinking water in Mongolia is still in infancy, elevated levels of arsenic have recently been reported in surface-, groundwater, soils/sediments and urban vegetation for several locations in this river basin [8-9]. This appears to be mostly related to mining activities and the coal combustion process containing trace amounts of arsenic [10-12]. Previous studies reported that natural rocks collected from Gatsuurt gold mine contain $46.986 \mathrm{mg} / \mathrm{kg}$ of arsenic which might have been caused by geological rocks type itself nearby this area [13]. An average arsenic content in the tailing dam sediment of Boroo gold mine was measured at 4.419 $\mathrm{mg} / \mathrm{kg}$ [11].

The main aim of this study was to contribute to a better understanding of the geochemical distribution of arsenic in water bodies in gold mining area located in Kharaa river basin. Moreover, water quality assessment associated with contamination of heavy metals and chemical characterization of surface and groundwater has been evaluated based on revealed data.

\section{MATERIALS AND METHODS}

Study site: Located between latitudes $47^{\circ} 53^{\prime}$ and $49^{\circ} 38^{\prime} \mathrm{N}$, and longitudes $105^{\circ} 19^{\prime}$ and $107^{\circ} 22^{\prime} \mathrm{E}$, the Kharaa river originates in the Khentii mountains in northern Mongolia and flows north to northwestwards into the Orkhon river, thus being part of the Selenge river basin, which is the main source region of lake Baikal (Figure 1). The total catchment area of Kharaa river basin is $17667.7 \mathrm{~km}^{2}$, average altitude of the whole catchment is $1.167 \mathrm{~m}$, and long-term mean discharge is $12 \mathrm{~m}^{3} \mathrm{~s}^{-1}$. From its headwaters in the Khentii mountains to the outlet in the Kharaa river cuts across several major morphological and geological units and fault zones of the Mongol-Baikal lake tectonic system. The river basin contains three different morphological units such as (1) the upper course of the Kharaa comprised the subbasins Mandal river, Bayangol river (Tuv province), Sugnugur river, Kharaa river and Tunkhel river which is characterized by mid to high mountain ranges of the Khentii mountains with steep valley slopes, (2) the middle reaches comprised subbasins Boroo, Zagdal and Kharaa river which is dominated by broad valleys with significant terrace levels and hilly uplands that placed the most of the gold deposits in this region, and (3) the lower reaches comprised subbasins Bayangol river (Selenge province) and Kharaa river with typical of open steppe and lowland landscape. Climatically the Kharaa river basin is characterized by anextreme continental climate with harsh, cold and dry winters and short, hot summers. Therefore, the mean monthly temperatures in January are ranging between minus $20^{\circ} \mathrm{C}$ and minus $30^{\circ} \mathrm{C}$ (with minimum temperatures dropping to minus $40^{\circ} \mathrm{C}$ ).

Sample collection: The field survey was conducted from 26 June to 3 July, 2016 in the area belonging to seven sums (Bayangol, Mandal, Bayanchandmani, Bornuur, Jargalant, Sumber, Batsumber) of 2 provinces (Tuv, Selenge) located in Kharaa river basin. During the expedition, deep and shallow groundwater wells, rivers and springs were sampled according to guidance on data collection for use in developing a quality Assurance project plan EPAQA/G-5S and the sampling points were illustrated in Figure 1. A total of 100 water samples were collected for analysis of general chemical (cation, anion and total hardness) and heavy metals $(\mathrm{Bi}, \mathrm{Cd}$, $\mathrm{Cu}, \mathrm{Cr}, \mathrm{Mn}, \mathrm{Mo}, \mathrm{Ni}, \mathrm{Pb}, \mathrm{Se}, \mathrm{Sb}, \mathrm{Te}, \mathrm{Zn}, \mathrm{Hg}, \mathrm{Fe}, \mathrm{F}$ ), as well as As species. Routinely, water samples for onsite measurements of water quality were taken with a 1 I glass from water sources. Duplicate water samples for analysis of heavy metals and general chemical analysis were collected in 1.5 I bottles. For total As analysis, samples were taken at 0.5 I bottles without any sterilization whereas duplicate samples for As speciation including As (III) and As (V) were acidified by concentrated hydrochloric $(\mathrm{HCl})$ and nitric acid $\left(\mathrm{HNO}_{3}\right)$, respectively, for stabilization in the field.

Analysis: Water quality including measurements of temperature and $\mathrm{pH}$, electrical conductivity $(\mathrm{EC})$, and dissolved oxygen (DO) was measured on-site with the portable multi-parameter measuring device (Hanna multi parameter HI98194, Germany). Furthermore, 21 heavy metals (As, Al, Ba, Cr, Cu, Fe, Mn, P, Zn, Be, $\mathrm{Co}, \mathrm{Ni}, \mathrm{Mo}, \mathrm{Se}, \mathrm{Cd}, \mathrm{Sb}, \mathrm{Te}, \mathrm{Hg}, \mathrm{Pb}, \mathrm{Th}, \mathrm{U})$, anions $\left(\mathrm{Cl}^{-}\right.$, $\left.\mathrm{SO}_{4}^{2-}, \mathrm{NO}_{2}^{-}, \mathrm{NO}_{3}^{-}, \mathrm{CO}_{3}^{2-}, \mathrm{HCO}_{3}^{-}, \mathrm{F}^{-}\right)$, as well as cations $\left(\mathrm{K}^{+}, \mathrm{Na}^{+}, \mathrm{NH}_{4}^{+}, \mathrm{Ca}^{2+}, \mathrm{Mg}^{2+}\right)$ were selected for the water quality assessment. The water samples were then analyzed by the inductively coupled plasma mass spectrometry (ICP-MS) and chemical analysis. Arsenic speciation (III, V) in water samples were analyzed by LCICPMS. An analytical error and uncertainty were $1.65 \%$ and \pm 0.4330 for As concentration (in case of station 33 as for representative), respectively. The detection limitation of analytical measurements was $0.03 \mu \mathrm{g} / \mathrm{l}$. The water was evaluated by using Kurlov equation and Alekyn water quality classification, respectively, to reveal the chemical composition [14]. All detected data in water were compared to the value in the National drinking water quality standard [15].

\section{RESULTS AND DISCUSSION}

Although totally 100 of water samples from water bodies including river, spring and wells located in this river basin, we mostly proposed to present water quality and content of heavy metal ions in surface and groundwater in Mandal sum of Selenge province because two strategic gold mining deposits, Boroo and Gatsuurt, are placed in this area.

Chemistry of surface and groundwater: A total number of 39 water samples including 26 - river, 3 - spring and 10 - groundwater were collected from designated sites in this area. Mean concentration of general chemical parameters measured in water samples for water quality is presented in Table 1. The $\mathrm{pH}$ in the river water samples has been observed to be in range of 6.06-7.98 with average 7.19 , in range of $6.27-7.47$ with an average of 7.16 in groundwater while it was ranged in 6.64-7.41 with average of 7.11 in spring water, which are within the safe limits of 6.5-8.5 recommended by Mongolian drinking water quality standard [15]. Electrical conductivity (EC) values varied widely between 0.45 and $6.22 \mathrm{mS} / \mathrm{m}$ in 


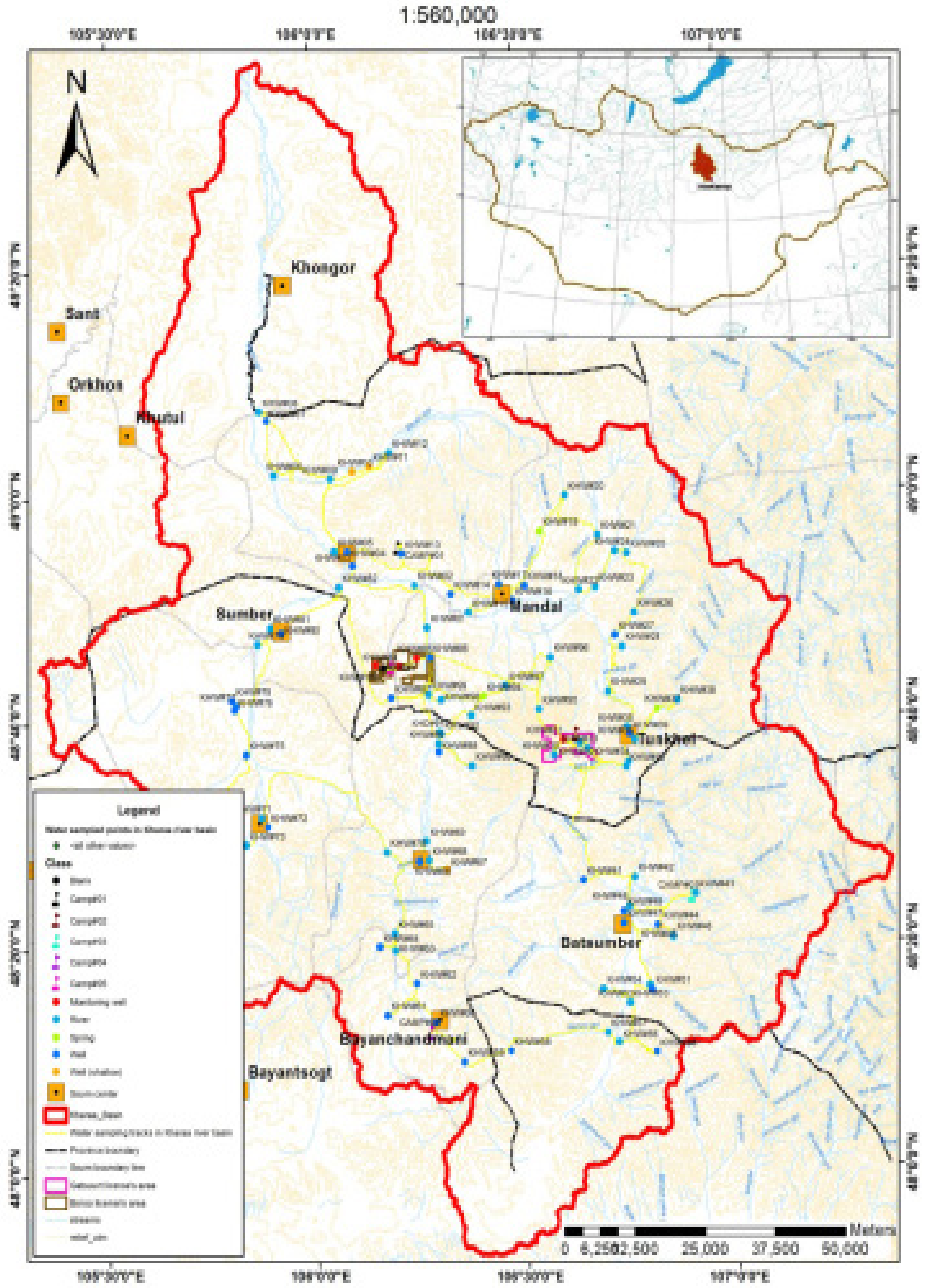

Fig. 1. Location of surface and groundwater sampling in the Kharaa river basin 
river water, the highest value observed at the station 20 near to headwater of Orkhiroo river. In spring water, the mean value was $3.97 \mathrm{mS} / \mathrm{m}$ showing the lower value than available limits of $10.00 \mathrm{mS} / \mathrm{m}$. River water at stations 20-22 had a relatively high hardness ranged in $5.30-5.80 \mathrm{mg}$-eq/l whereas it was not exceeded 4.0 $\mathrm{mg}-\mathrm{eq} / \mathrm{l}$ at other stations throughout the area. There was an exception with higher hardness value $(7.05 \mathrm{mg}$ eq/l) in spring water at station 37 than recommended permissible level (7.0 mg-eq/l) by MNS 0900:2005. This high hardness observed at those stations can be related to high $\mathrm{Ca}^{2+}, \mathrm{Mg}^{2+}$ and $\mathrm{HCO}_{3}^{-}$ions (ranged in 60.12-83.17 mg/l for $\mathrm{Ca}^{2+}$ and 20.05-27.95 mg-eq/l for $\mathrm{Mg}^{2+}$ ). Calcium is an essential element for all organisms about $55.4 \%$ of prevalent magnesium hardness in water content. A mean hardness suggests that groundwater in Mandal sum area is referred to soft water.

Mean values of DO concentration at all stations for river and spring water were 8.37 and $10.10 \mathrm{mg} / \mathrm{l}$, respectively, indicating that river water quality is relatively clean.

In contrast, DO content in groundwater varies depending on temperature, turbulence, well depth and atmospheric pressure. The solubility of oxygen increases as temperature decrease. Moreover, colder and deeper fresh waters have the capability to hold higher concentrations of DO. This is consistent with our results showing that high DO concentrations ranged in $13.80-27.30 \mathrm{mg} / \mathrm{l}$ were measured when well depth was

Table 1.Mean values of chemical contents in three different waters in Mandal, Selenge

\begin{tabular}{|c|c|c|c|c|c|c|c|c|c|c|c|c|c|c|c|c|c|c|c|c|}
\hline \multirow{2}{*}{$\begin{array}{l}\text { Water } \\
\text { type }\end{array}$} & \multirow{2}{*}{$\begin{array}{c}\text { Sample } \\
\text { number } \\
\{n\}\end{array}$} & \multirow{2}{*}{ Charactoristic } & \multirow[b]{2}{*}{$\mathrm{pH}$} & \multicolumn{12}{|c|}{$\mathrm{mgll}$} & \multirow[b]{2}{*}{ Residue } & \multirow[b]{2}{*}{ Oxidation } & \multirow[b]{2}{*}{ DO } & \multirow{2}{*}{$\begin{array}{c}\text { Hardness } \\
\text { mgeoll }\end{array}$} & \multirow{2}{*}{$\begin{array}{c}E C \\
m 5 i m\end{array}$} \\
\hline & & & & $\kappa$ & $\mathrm{Na}^{\circ}$ & $\mathrm{NH}_{4}^{+}$ & $\mathrm{Ca}^{20}$ & $\mathrm{Mr}^{\mathrm{T}}$ & $\mathrm{CO}^{3}$ & $\mathrm{HCO}_{1}{ }^{\mathrm{n}}$ & $\mathrm{H}_{3} \mathrm{siO}$ & cr & $\mathrm{SO}_{4} \mathrm{x}$ & $\mathrm{NO}_{1}^{\prime}$ & $\mathrm{NO}_{i}$ & & & & & \\
\hline river & 26 & \multirow{3}{*}{$\begin{array}{l}\text { MENN } \\
\text { VALUE }\end{array}$} & 7.18 & 1.80 & 8.01 & 0.30 & 53.64 & $10.4 \theta$ & 3.90 & 13528 & 11.96 & 6.85 & 27.14 & 0.11 & 2.10 & 178.73 & 8.24 & 8.37 & 2.55 & 2.39 \\
\hline spring & 3 & & 7.11 & 123 & 13.61 & 0.13 & 62.55 & 22.07 & 3.00 & 279.66 & 12.55 & B.51 & 30.39 & 0.01 & 3.68 & 304.67 & 5.28 & 10.10 & 493 & 3.97 \\
\hline \multirow[t]{2}{*}{ wol } & 10 & & 7.12 & 2.32 & 28.12 & 0.00 & 48.40 & 18.36 & 450 & 211.73 & $11 . \mathrm{AS}$ & 2351 & 46.51 & 0.05 & 4.78 & 25000 & $19 a$ & 14.76 & 399 & 5.69 \\
\hline & & MNB 0200:2005 & 6.585 & na & 200.00 & 1.50 & 100.00 & 30.00 & $\mathrm{ma}$ & na & na & 350.00 & 500.00 & 1.00 & 50.00 & 100000 & $\mathrm{na}$ & $\mathrm{n}$ & 700 & กล \\
\hline
\end{tabular}

na: not available

Table 2. Mean values of heavy metal concentration $(\mu \mathrm{g} / \mathrm{l})$ in three different waters in Mandal, Selenge

\begin{tabular}{|c|c|c|c|c|c|c|c|c|c|c|c|c|c|c|c|c|c|c|c|c|c|c|c|c|c|}
\hline \multirow{2}{*}{$\begin{array}{l}\text { Water } \\
\text { type }\end{array}$} & \multirow{2}{*}{$\begin{array}{c}\text { Sample } \\
\text { number } \\
\text { (n) }\end{array}$} & \multirow{2}{*}{ Cherncteriatic } & \multirow{2}{*}{$\begin{array}{l}\text { As } \\
\text { total }\end{array}$} & \multicolumn{2}{|c|}{ As } & \multirow[b]{2}{*}{ Ni } & \multirow[b]{2}{*}{ No } & \multirow[b]{2}{*}{ se } & \multirow[b]{2}{*}{ ed } & \multirow[b]{2}{*}{$s b$} & \multirow[b]{2}{*}{ To } & \multirow[b]{2}{*}{$\mathrm{Hg}$} & \multirow[b]{2}{*}{$\mathrm{Pb}$} & \multirow[b]{2}{*}{ Th } & \multirow[b]{2}{*}{$u$} & \multirow[b]{2}{*}{ All } & \multirow[b]{2}{*}{ Da } & \multirow[b]{2}{*}{$\mathrm{Cr}$} & \multirow[b]{2}{*}{$\mathrm{Cu}$} & \multirow[b]{2}{*}{ Pe } & \multirow[b]{2}{*}{$M n$} & \multirow[b]{2}{*}{ P } & \multirow[b]{2}{*}{$2 n$} & \multirow[b]{2}{*}{ De } & \multirow[b]{2}{*}{ Co } \\
\hline & & & & (IIII & [V] & & & & & & & & & & & & & & & & & & & & \\
\hline \multirow{2}{*}{ sar } & & MEAN & 4.10 & 0.46 & 4.27 & 1.42 & 1.35 & 0.68 & 0.02 & 0.32 & ny & $\mathrm{ng}$ & $\mathrm{ma}$ & 0.09 & 2.06 & 306.63 & 20.58 & 2.41 & na & 18200 & 89.00 & 59.00 & $\mathrm{ng}$ & ny & 0.15 \\
\hline & & DEV & 6.84 & a & 700 & 065 & 1.35 & 0.45 & 0.01 & 0.12 & กล & $\mathrm{na}$ & na & 0.13 & 291 & 27200 & Q.13 & 1.44 & na & 82.87 & na & 11.31 & $\mathrm{n}$ & กล & 0.00 \\
\hline \multirow{2}{*}{ sping } & & MEAN & 10.60 & na & 8.89 & 203 & 3.13 & 1.23 & 0.03 & $n$ & ne & $\mathrm{nth}$ & na & 0.011 & $12 \mathrm{B2}$ & ne & 1600 & 4.39 & ne & na & nat & ne & not & ne & 0.17 \\
\hline & & STDEV & 17.07 & na & $\mathrm{ng}$ & 0.76 & 2.04 & 0.80 & $\mathrm{~ns}$ & ne & na & $\mathrm{ng}$ & $\mathrm{ma}$ & 0.001 & 1284 & na & $\mathrm{ns}$ & 2.52 & ra & $\mathrm{ng}$ & $\mathrm{ng}$ & na & $\mathrm{ng}$ & ma & 0.05 \\
\hline \multirow{3}{*}{ wedl } & \multirow{3}{*}{10} & EAN & 1.18 & 0.84 & 0.97 & 192 & 4.47 & 2.47 & na & 0.40 & กล & $\mathrm{na}$ & na & 0.011 & 1371 & na & 1525 & 330 & na & na & na & na & 12000 & กล & 0.25 \\
\hline & & STDEV & 0.81 & $a$ & 0.75 & 0.67 & 3.42 & 2.61 & na & 0.00 & กล & na & na & 0.011 & 18.46 & กล & 4.03 & 0.96 & na & na & $n$ & na & $n$ & กล & 0.33 \\
\hline & & MNs $0000-2005$ & 10.00 & a & $\mathrm{n}$ & 20.00 & 70.00 & 10.00 & 3.00 & $\mathrm{na}$ & กล & 0.50 & 10.00 & กล 1 & 1500 & na & 700.00 & 15000 & 000.0 & 30000 & 100.00 & na & 5000.00 & 0.20 & na \\
\hline
\end{tabular}

na: not available

and is incorporated into the shells of many aquatic invertebrates, as well as the bones of vertebrates. Calcium concentrations in natural waters are typically $<15 \mathrm{mg} / \mathrm{l}$. For waters associated with carbonate-rich rocks, concentrations may reach 30-100 mg/l. Therefore, water at the most of stations with high dissolved $\mathrm{Ca}^{2+}$ may be came from geological source. Natural concentrations of magnesium in fresh-waters may range from 1 to $>100 \mathrm{mg} / \mathrm{l}$, depending on the rock types within the catchment. It arises principally from the weathering of rocks containing ferromagnesium minerals and from some carbonate rocks. Magnesium occurs in many organometallic compounds and inorganic matter, since it is an essential element for living organisms. Although magnesium is used in many industrial processes, these contribute relatively little to the total magnesium in surface waters. In our study, the dissolved $\mathrm{Mg}^{2+}$ concentrations in all river water have been varying in 1.82-27.95 mg/l with mean of $11.02 \mathrm{mg} / \mathrm{l}$ presenting low values with respect to the standard. In contrast, station 37 had high $\mathrm{Mg}^{2+}$ concentration (41.92 $\mathrm{mg} / \mathrm{l}$ ) rather than the value described in MNS 0900:2005 [15]. For groundwater, it was varied in $1.35-6.10 \mathrm{mg}-\mathrm{eq} / \mathrm{l}$ with a mean of $4.07 \mathrm{mg}-\mathrm{eq} / \mathrm{l}$ at all stations. The maximum value $(6.10 \mathrm{mg}-\mathrm{eq} / \mathrm{l})$ observed at station 84 is related to about $40 \mathrm{~m}$ with low temperatures $\left(4.47-7.19^{\circ} \mathrm{C}\right)$ at stations from 83 to 87 . Unpolluted waters contain small amounts of ammonia and nitrogen compounds, usually $<0.1 \mathrm{mg} / \mathrm{l}$ as $\mathrm{N}$. Total ammonia concentrations measured in surface waters are typically less than $0.2 \mathrm{mg} / \mathrm{l}-\mathrm{N}$ but may reach 2-3 mg/l-N. Higher concentrations could be an indication of organic pollution such as from domestic sewage, industrial waste and fertilizer run-off. The concentration of $\mathrm{NH}_{4}^{+}$at all stations was varied between 0.02 and $2.13 \mathrm{mg} / \mathrm{l}$, and the highest concentration with $2.13 \mathrm{mg} / \mathrm{l}$ was observed at station 98 around an estuary of Zuunmod river. This high value can be caused by the animal manure mixed with river water over there. Nitrates and nitrites were all within the maximum levels of the standard (50.0 and $1.0 \mathrm{mg} / \mathrm{l}$, respectively) in all the stations. As estimation by Kurlov equation for determination of chemical component of water at all the stations, about $89.6 \%$ of total stations belonged to the water classification of hydrocarbonate-sulphate with respect to calcium-magnesium-sodium section. In the headwater of Gatsuurt river (station 30) and Baavgait river (station 97), it is classified as water for sulphatehydrocarbonate-chloride with respect to calciummagnesium-sodium section. Result at only 1 station, near to downstream of Gatsuurt river (station 32), shows 


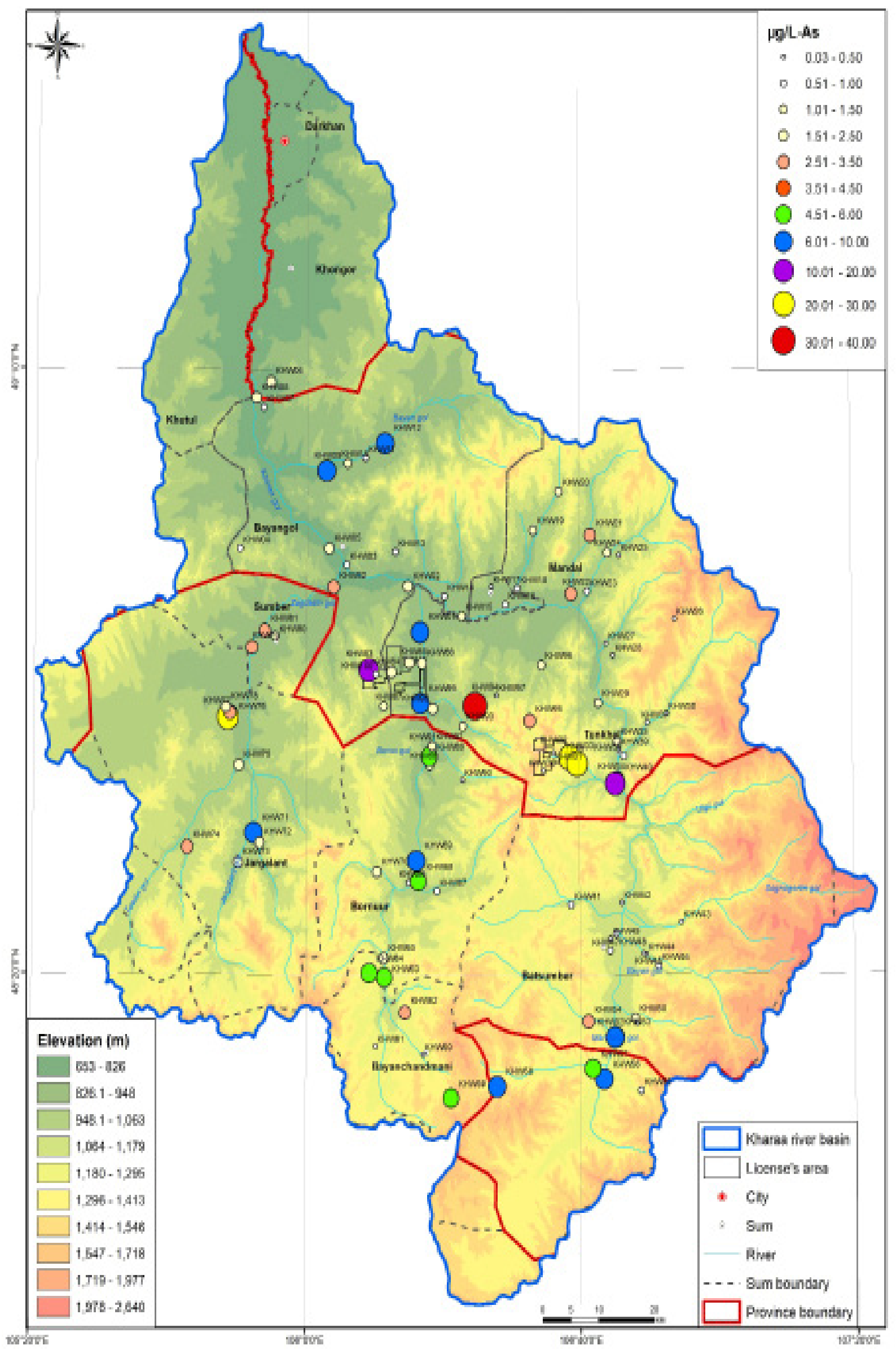

Fig. 2. Arsenic distribution in surface and groundwater in Kharaa river basin 
that water type is in classification of hydrocarbonatechloride with respect to calcium-magnesium-sodium section. The difference water types between headwater and estuary in Gatsuurt river might have due to water flow rate, for instance, some ions can precipitate in river sediment when the flow rate is slow in the estuary.

Heavy metal contents: The concentrations of dissolved trace metals including $\mathrm{Ba}, \mathrm{Cr}, \mathrm{Cu}, \mathrm{Fe}, \mathrm{Mn}, \mathrm{Zn}, \mathrm{Be}$, $\mathrm{Co}, \mathrm{Ni}, \mathrm{Mo}, \mathrm{Se}, \mathrm{Cd}, \mathrm{Sb}, \mathrm{Hg}, \mathrm{Pb}, \mathrm{Te}$ and $\mathrm{Th}$ in all the samples analyzed were within the acceptable levels of the Mongolian drinking water quality standard (Table 2). Station 97 had high Al concentration with 672.00 $\mu \mathrm{g} / \mathrm{l}$ which is above the value recommended by WHO $(500 \mu \mathrm{g} / \mathrm{l})$. Uranium $(U)$ concentrations in the river water samples from all stations have been found to be varying between 0.09 and $12.00 \mu \mathrm{g} / \mathrm{l}$ with mean value of $2.26 \mu \mathrm{g} / \mathrm{l}$ while it was ranging in 1.56-26.70 $\mu \mathrm{g} / \mathrm{l}$ with mean value $12.62 \mu \mathrm{g} / \mathrm{l}$ in spring water. Slightly higher mean $U$ value with $13.39 \mu \mathrm{g} / \mathrm{lwas}$ observed in groundwater. The highest $U$ concentration was observed in spring water nearby Gatsuurt-Boroo improved road (at station 94) which can be caused by geological configuration of our survey area. We mapped the arsenic distribution in water bodies in this river basin with 1:500000 scale based on analytical results and it presented in Figure 2. Although the As concentration in river waters in this area was mainly low, it exceeded the $10.0 \mu \mathrm{g} / \mathrm{l}$ either Mongolian water quality standard [15] or WHO [16] threshold for drinking water in three cases, which made $11.5 \%$ of all measurements, in Gatsuurt and Balj river. The maximum concentration of As was measured at 2 points in downstream of Gatsuurt River with values of 23.30 and $26.50 \mu \mathrm{g} / \mathrm{l}$, respectively. We did not find a high As concentration in headwater of the river. As measured by Enkhdul et al [17], the arsenic concentration was $136 \mathrm{mg} / \mathrm{kg}$ for the sediment in middle part of Gatsuurt river. Therefore, enriched As in downstream water in our survey area can be related to binding of As to the river sediment itself. In other words, high concentration of As along river might have reduced by the dilution with larger water volume, which is common effect in a river system. A general pattern says that $A s(V)$ was the dominant specie which can consider as total As content in all the river water. As(III) detected at several stations such as station 1, 21, 23, 33, 34, 93 and 99 was negligible. We have done totally 3 samplings from spring water in Mandal sum and, specifically, station 94 had high As concentration with $30.30 \mu \mathrm{g} / \mathrm{l}$. It was 3 times greater than the value prescribed in both MNS 0900:2005 [15] and WHO [16]. Dalai and Dorjbaatar, [18] reported that bedrock at significant depth around survey area is basically of granite origin with rock erosion products being loam, sandy loam, sand and gravel, therefore, As can present as a result of geological processes occurred in spring water. By the speciation, As $(\mathrm{V})$ was dominant contributor with $28.0 \mu \mathrm{g} / \mathrm{l}$ to total As while As(III) was measured at $2.30 \mu \mathrm{g} / \mathrm{l}$. This pattern indicates that most of As was relatively stabilized form with less toxic characterization in spring water.

Previously, the mean As concentrations were in the range of $1.00-2.50 \mu \mathrm{g} / \mathrm{l}$ for the groundwater bodies in Mandal sum investigated by Hoffman et al. [10]. This is agreed with our results, which found that mean As was $2.45 \mu \mathrm{g} / \mathrm{l}$. However, in single case at station 83 (borehole HG-3 at Boroo Gold), slightly high level $(12.60 \mu \mathrm{g} / \mathrm{l})$ of As exceed the maximum tolerable level of the drinking water standard of $10.00 \mu \mathrm{g} / \mathrm{l}$. The surrounding geology

Table 3. Statistics and As distribution in Kharaa river indrafts (Gatsuurt, Balj)

\begin{tabular}{|c|c|c|c|c|c|c|}
\hline \multirow{3}{*}{ № } & \multirow{3}{*}{ Sample } & \multirow{3}{*}{ Location } & \multirow{3}{*}{ Sampling point } & \multirow{2}{*}{$\begin{array}{l}\text { As } \\
\text { total }\end{array}$} & \multicolumn{2}{|c|}{ As } \\
\hline & & & & & (III) & (V) \\
\hline & & & & \multicolumn{3}{|c|}{$\mu \mathbf{g} / \mathbf{l}$} \\
\hline 1 & KHW\#30 & \multirow{8}{*}{$\begin{array}{l}\text { Mandal } \\
\text { Selenge }\end{array}$} & Headwater of Gatsuurt river & $<0.03$ & - & $<0.03$ \\
\hline 2 & KHW\#32 & & downstream of Gatsuurt river (1) & 23.30 & $<1$ & 23.30 \\
\hline 3 & KHW\#33 & & downstream of Gatsuurt river (2) & 26.50 & 0.50 & 26.00 \\
\hline 4 & KHW\#40 & & Estuary of Balj river, Tunkhel 5th bag & 10.30 & - & 10.30 \\
\hline 5 & KHW\#34 & & Confluence of Kharaa-Balj rivers, Tunkhel $5^{\text {th }}$ bag & 2.95 & 1.00 & 1.95 \\
\hline 6 & KHW\#35 & & $\begin{array}{l}\text { West side of Kharaa river, Underside of Tunkhel } \\
\text { bag, Tunkhel 5th bag }\end{array}$ & 1.13 & - & 1.13 \\
\hline 7 & KHW\#36 & & $\begin{array}{l}\text { Confluence of Tunkhel-Kharaa rivers, } \\
\text { Tunkhel } 5^{\text {th }} \text { bag }\end{array}$ & 0.60 & - & 0.60 \\
\hline 8 & KHW\#38 & & West side of Tunkhel river, Tunkhel $5^{\text {th }}$ bag & 0.40 & - & 0.40 \\
\hline & \multirow{5}{*}{\multicolumn{2}{|c|}{$\begin{array}{l}\text { Statistics } \\
\qquad(n=8)\end{array}$}} & Max & 26.50 & 1.00 & 26.00 \\
\hline & & & Min & 0.40 & 0.50 & 0.40 \\
\hline & & & Median & 2.95 & 0.75 & 1.95 \\
\hline & & & SD & 11.22 & 0.35 & 11.19 \\
\hline & & & Mean & 9.31 & 0.75 & 9.10 \\
\hline \multicolumn{3}{|c|}{$\begin{array}{l}\text { Mongolian drinking water } \\
\text { quality standard }\end{array}$} & MNS 0900:2005 & 10.0 & - & - \\
\hline
\end{tabular}


of the station 83 has been described as bedrock at the significant depth is generally of granitic origin location with rock erosion products being loam, sandy loam, sand and gravel [19]. Therefore, there could be a natural enrichment of As besides anthropogenic influence. The speciation test data suggested that $A s(V)$ is dominant contributor to total As at most stations. However, groundwater at stations 85 and 86 have mixture of both species. Concentration of $\mathrm{As}(\mathrm{III})$ and $\mathrm{As}(\mathrm{V})$ specie in all the station is not at considerable level, thus it is summarized that groundwater in this area was not contaminated by As since amount of $\mathrm{As}(\mathrm{V})$ almost equalized with total As.

As content in surface water in gold mining area: In this section, mining area has been considered as special classification for the evaluation of As. An average As concentration in river flowing in licensed area of Gatsuurt gold mine (station 32, 33), which domains by "Centerra gold Mongolia", was 2 times higher $(25.00 \mu \mathrm{g} / \mathrm{l})$ than that of permissible level. This high value might be observed as a result of either natural geogenic processes or an accumulation of As in river sediment. Moreover, As contamination around this area can be caused by gold mining processes by illegal workers before 2000. Our results were agreed with those of previous results [10] which indicating that surface water was contaminated by As. It is possible to neutralize and treat As in water related to gold mining activity by using conventional and selected methods under strict controlling.

We studied As content in several sampling points in the river which receives As polluted water to reveal how higher amount of As in Gatsuurt river is distributing to further small rivers. As showed in Table 3, As concentration in headwater was negligible, however, its concentration was intensively increased to 23.30-26.50 $\mu \mathrm{g} / \mathrm{l}$ in middle of this river. River then flows to Balj river located in area belonging to Tunkhel 5th bag and As concentration was decreasing two magnitude of orders at station 40. Basically, occurrence of natural purification in the river system is common process in the nature. Therefore, decreased trend of As at station 40 can be related to natural processes. This process was proved by the small amount of As detection with 2.95-0.40 $\mu \mathrm{g} / \mathrm{l}$ in Kharaa river water receiving Balj river, which is one of indrafts. There was no surface water in licensed area of Boroo gold mining. Therefore, we have done duplicate water sampling from Boroo river nearby to this area. Analytical results at stations 1 and 99 (Mandal sum, Selenge province) gave us that total As concentrations were ranging in 6.05-6.25 $\mu \mathrm{g} / \mathrm{l}$, which is lower than standard value. This indicates As contamination in water was negligible at this river.

\section{CONCLUSION}

The Kharaa river basin is one of the main tributaries of the Orkhon-Selenge river system, which ultimately drains to lake Baikal. An assessment for the water quality of surface and groundwater in this basin which involved in 7 soum of 2 provinces (Selenge and Tuv) has been done on the basis of physico-chemical analysis. The main target was to reveal the spatial distribution of As concentration in designated river basin. Most of station in all the area was dominated by $\mathrm{As}(\mathrm{V})$ specie which is in less toxic form than As(III). An average concentration of total As in surface water of the Kharaa river basin was $4.04 \mu \mathrm{g} / \mathrm{l}$ with wide range in $0.07-30.30 \mu \mathrm{g} / \mathrm{l}$ whereas it was $2.24 \mu \mathrm{g} / \mathrm{l}$ in groundwater. Compared to Mongolian drinking water standard (MNS 0900:2005), an average concentration of As in this basin was low. Maximum As concentration was detected at station 94 in the area of Kherkh 4-bag, Mandal sum. As analysis in surface water in licensed area of Gatsuurt gold mining showed that its average concentration was $24.90 \mu \mathrm{g} / \mathrm{l}$ presenting 6 times higher value than that ofvalue for Kharaa river basin and it was 2 times higher than standard level as well. In Boroo river nearby Boroo gold mining area, As concentration in water was ranged in 6.05-6.25 $\mu \mathrm{g} / \mathrm{l}$, showing lower value than permissible level. For groundwater, an average As concentration in Boroo area was slightly higher than average As of Kharaa river basin, but it was fitted with standard requirement. As seen from overall results, detected As with low and high concentration in natural water may resulted by natural geological or chemical processes in case of Kharaa river basin. Further study should have been done study on seasonal variation of As in water bodies in this region.

\section{REFERENCE}

1. Baig J.A., Kazi T.G., Arain M.B., Afridi H.I., Kandhroa G.A et al. (2009) Evaluation of arsenic and other physico-chemical parameters of surface and groundwater of Jamshoro, Pakistan. Water Res. 166, 662-669.

2. Smith A.H., Lingas E.O., Rahman M. (2000) Contamination of drinking-water by arsenic in Bangladesh: a public health emergency. Bulletin of WHO, 78, 1093-1103.

3. Smedley P. L., Edmunds W. M., Pelig-Ba K.B. (1996) Mobility of arsenic in groundwater in the Obuasi area of Ghana. In: Environmental Geochemistry and Health, Geological Society Special Publication. London, 163-181.

4. Lee S.W., Lee B.T., Kim J. Y., Kim K. W., Lee, J. S. (2006) Human risk assessment for heavy metal and As contamination in the abandoned metal mine areas, Korea. Environ. Monit. Assess., 119, 233244.

5. Huang S. S., Liao Q. L., Hua M., Wu X. M., Bi K. Set al. (2007) Survey of heavy metal pollution andassessment of agricultural soil in Yangzhong district, Jiangsu Province, China. Chemosphere, 67, 2148-2155.

6. Espinosa E., Armienta M. A., Cruz O., Aguayo A., Ceniceros N. (2009)Geochemical distribution of arsenic, cadmium, lead and zinc in river sediments affected by tailings in Zimapan, a historical polymetalic mining zone of Mexico. Environ. Geol. 58, 1467-1477.

7. Yellishetty M., Ranjith P. G., Kumar D. L. (2009) Metal concentrations and metal mobility in 
unsaturated mine wastes in mining areas of Goa India, Resources. Con- serv. Recycle, 53, 379-385.

8. Olkhanud PB. (2012) Survey of Arsenic in Drinking Water in the Southern Gobi region of Mongolia. Master thesis, Johns Hopkins University. USA

9. Pfeiffer M., Batbayar G., Hofmann J., Siegfried K., Karthe D et al. (2013) Investigating arsenic (As) occurrence and sources in ground, surface, waste and drinking water in northern Mongolia. Environ Earth Sci., 73(2), 649-662.

10. Hofmann J., Venohr M., Behrendt H., Opitz D. (2010) Integrated waterresources management in central Asia: nutrient and heavy metalemissions and their relevance for the Kharaa river Basin, Mongolia. Water Sci.Technol., 62(2), 353-363.

11. Inam E., Khantotong S., Kim K.W., Tumendemberel B., Erdenetsetseg S et al. (2011) Geochemical distribution of trace elementconcentrations in the vicinity of Boroo gold mine, Selenge Province, Mongolia. Environ. Geochem Health, 33, 57-69.

12. Thorslund J., Jarsjo J., Chalov SR., Belozerova E. V. (2012) Gold mining impact on riverine heavy metal transport in a sparsely monitored region: the upper Lake Baikal Basin case. J. Environ. Monit., 14(10), 2780-2792.

13. Tsetsegmaa T., Darjaa T., Dorj D. (2009) Use of nitrous oxide-acetylene flame for determination of arsenic by AAS in geological samples. Mong. $J$ Chem. Sci., 7(315), 4-7.
14. Голева Г.А. (1977). Гидро-геохимия рудных элементов. Москва

15. MNS 0900:2005 Safety of environment \& health protection: drinking water standard. Mongolian National Center of Standardization and Metrology, Ulaanbaatar. (in Mongolian)

16. WHO (2011) Guidelines for drinking water quality 4th edition. World Health Organization, Geneva.

17. Enkhdul T., Darjaa T., Dorj D. (2010) Arsenic elimination in artifical lake of Gatsuurt gold mining area Mongolia. In: 2nd International symposium on health hazards of arsenic contamination of groundwater and its countermeasures, Miyazaki. 145-148.

18. Dalai D., Dorjbaatar E. (2008) Environmentally safe tailings storage facility of Boroogold mine, Mongolia, proceedings of IFOST- 2008 -3rd international forum on strategic technologies, art. no. 4602892 , 623-628.

19. Visoottiviseth P., Ahmed F. (2009) Technology for remediation and disposal of arsenic. Rev. Environ. Contam., 197, 77-128. 